of seveles allment. He wonld be confined to his bed or at lenst to his house. On the contrury he is now about his business. If the disense were elironfe bronchitls he would not have this pulse.] Says he has no fover it night; hands and feat nre not hot Does not persplre. [Ile has tuberculous fover, not yet hectle fever.] llice is a general view of the rational symptoms. Now of the physical. There is coviclently a slight dulness on the loft side con tristed with the right. I think there is slight dulness on the right aiso. 1 think the resiration is rough on both sldes and there is 110 cvident alstinction between the two sides-the left being more rough. Thls distinction was partictiarly perceptible posteriorly in the intersempular spaces. Aetion of henrt unusiany perecpitible to thi" ell, in all parts of chest. On the loft slde there is a

itch in the respliatory murmur. No rnles were perceptlble. In vlew of the foregoing history l consider it demonstrutive that this young man is the vletim of tubereulous disense of lungs. His fever judglng enecially from the tuberculous eever, predict that ac Whl succumb within six months, and very likely within three. meroly troubled with a slient cough. Ife has no apprehensions. II las no envities, no bectle-and yet he may contidently be proHo has no cavities, no hectle -and yet he may contidently be pronolne'd "loomed man. If the result contin this predetion th will certainly show thit attention to the points connected with the dinghosis of pulmonary tubereulosis enables the practitionel to hinve wlili the value of evidence bearing on the subject.

A pril 10, 1846 .

()et. 11, 1840. This person went to Iowa and passed the sunmer. lle returted recently and agala applled to me for ndvice. His cough and of her symptoms were about the sume us they were last April. H. lind lost littlo if any flesh. Hud taken no medseine. I did not examine him closely, but I could not discover on a generul cxumination that the disease had made any apprecinble progress. Ir Irowbrldge. Si., silw hlm with me, concluded in the dlagnosis of inciplent tuberculosis and jolned in advice to seck $\|$ warm climate for the winter. The patient has taken our advice, but his purticular destination I do not know. He promised to write.

That Dr. Flint should have grasped so clearly the diagnostic signifiennce of the various symptoms and signs of tuberculosis as early as 1846, shows the acuteness of his diagnostic ability. It seems worth while to publish this ease from a historical point.

Lawrason IBrown, Saranac Lake; N. Y.

\section{The Royal Order of Lions Fraud}

To the bilitor:-There is a fellow traveling over the country inducing the pluysicians to examine for his new order the "Royal Order of Lions" so called. He calls on two phy-

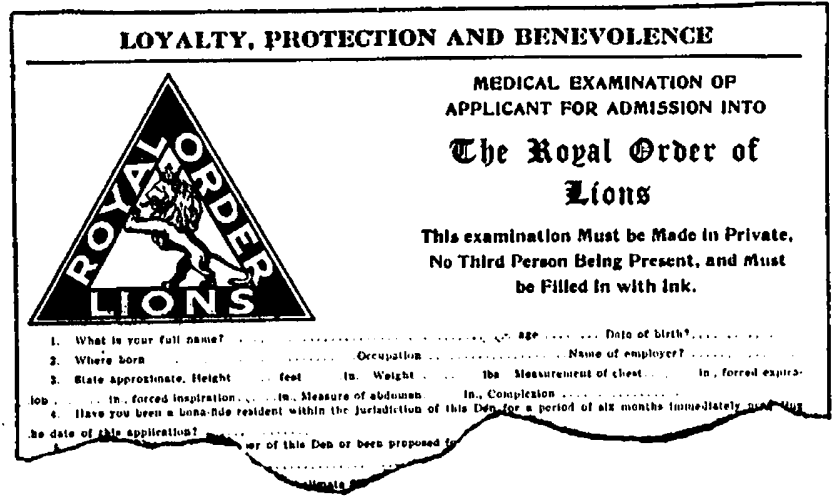

Photogruphe: reploduction (reduced) of part of the medleal examination and application blank used by the individual who persuaded ipysiedans to pay sh for the privilege of becont

sicimus in each city to obtain their services as examiners. lior this privilegre they pay $\$ 5.00$ in alvance. He gives you a receipt, bids you goodbye and that is the last you hear from him. He las roped in any number of doctors throughout Minnesota. There is no such order in existence so far ths we can Jearu. Enelosed find blank application and receipt. He is of slight buld, dark complexion, medium height, traveling with a woman whom he calls his wife; she is a dark, short, robust, pretty-fuced girl. I thought a notice conld be published in the next issue which might be the means of catching him somewhere.

\section{Charles F. Brigham, St. Cloud, Minn.} President St. Cloud Bourd of Health.

CoмmeNT.-The application blank, receipt and other printed matter which Dr. Brigham sends with his letter have notling on them to show where the headquarters of the Royal Order of Jions are loeated. The "Receipt and Admittance Caro Supreme Den of the World, Royal Order of Lions" has the name "J. L. Giblin, National Organizer" printed on it and the receipt is signed "J. R. Landnuer, Supreme Organizer." The latter uame also appears on some of the printed matter inat letails the wonderful advantages to be gained by joining" "The Fastest Growing, Fraternal, Social and Beneficial Order. The descriptive pamphlet states that this is "The Order Thin Does 'Things;" Dr. Brigham's letter indicates that it evidently loes.

\section{Fetal Death from Knotted Cord}

T'o the Liditor:-In 'TuE Jouns at, August 12, page $5^{63}$, Dr. Froehlich reports a cuse of cleatl of fetus due to twisting of the cord. In a somewhat similar case under my care, labor occurring on the date expected, the patient had not felt life for six days. Plıysical examination revealed absence of lieart sounls. A fully developed male child was born deal. There was a knot in the cord about 6 inches from the fetal eld drawn tightly enough to cut ofl the circulation completely. Mark 13escis, M.D., Clinton, Kan.

\section{Queries and Minor Notes}

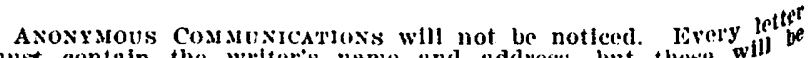
must contain the
omitted, on reguest.

\section{DIAGNOSIS OF a CASI OF NARCOJEISY}

To the Ellitor:- bave a somewhat bafling case under my eart and in view of the fact that the text-books, so fur as I have inver": guted, suggest very little on the subject, I appent to you. Histor The patient is a inaried woman, under midale age, the mother two healthy children. II'l pregnancles have been very ellsy gho of medlum height and welght is intelligent and looks the pletting Good health and says she fecls $1 t$, wlth the exception of some shap pains of an anginal charucter over the pericurdum, from which Intervils she is fres. She cune to North Dakota about ten she ngo and began almost at once to experlence great drowslbess.

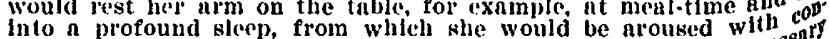
siclerible effort. To prevent it further lapse it would be necesents siclerable effort. To prevent at further lapse it would be necestime, fol her hisband to wak whe her in the cold air. $A t$ theep, evche while at the tuble, when chuting with friends or while holding to while at the table, when chiting with friends or while holding baby. When calrying her baby she had to be watched in ordig on wo prevented from dropping lt. When slie felt the attuck coming
while ut ber meal she would hurrledly sip a little tea from her

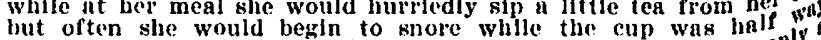
between the table and her lips. The sleep is profound, lasts only few minutes, nfter which the patient wakes perfectly refreshed and clear. Objective findings: Urinalysis is negative; the chest ar ubdominal organs ure normal; the vision is good; the pupils act equal in size and active to jight and accommodation; no the symptoms of intracranial tumor or cpllepsy are present. $\Lambda$ condition is very perplexing I slivuld greatly appreclate advice. $G$

Answer.-The cuse nppears to belong to that rare and inter" rsting, thougl obscure, condition called "nareolepsy," whj" Gelineau first deseribed in the fazette des Hopitaux, 1880, (120. In the Archives Gín. de Aédecine, 1905, No. 25, Ray mond succinctly defines true narcolepsy as a condition charac terized by a sudden and irresistible inclination to sleep, occli ing during the lours not usually spent in normal sleep ant appearing at irregular intervals, lasting a variable period in time. The person so affected may be overpowered by sleep d the midst of lis ordinary occupation and at most unexpecter moments, even during meals at table. Authorities still difn. in respect to the proper place of narcolepsy in the classifie tion of diseases. All agree in calling it a functional neur $0^{5}$ when it is not symptomatic of brain tumor, syphilis or anto intoxication. Although Gelineau described nurcolepsy as a independent neurosis, most neurologists agree with 10 ("Twentieth Century Pructice of Medicine," p. 501-503), w classes it among the symptoms of hysteria. In speaking sleeping attucks, he says among other things: "In hysterich subjects we sometimes observe sudden but short-timed attach of deep slumber, which Gelineau has designated by the nan of marcolepsy, but which are always symptomatic, as Ball to has well shown." Continuing, Fere compares these crises of postepileptic stertor, but he regards them as larval forms hystero-epilepsy, which is true hysteria, according to our lates conceptions of this symptom-complex. In conclusion, he quote Pitres as having reported the case of $a$ woman who liad to yield to the sleeping attack even when she ran about trying 